\title{
COMMUNITY ENGAGEMENT, SERVICE LEARNING AND STUDENT SOCIAL RESPONSIBILITY: IMPLICATIONS FOR SOCIAL WORK EDUCATION AT SOUTH AFRICAN UNIVERSITIES: A CASE STUDY OF THE UNIVERSITY OF FORT HARE
}

\section{Margie Maistry}

\section{INTRODUCTION}

In aspiring towards promoting a developmental state after 1994, the democratic government of South Africa framed its social policies within a developmental paradigm, which underpins its attempt to transform the public sector. Higher education institutions (HEIs) are considered a critical part of the post-apartheid transformation agenda, given that most universities in South Africa were created in line with the oppressive regime of apartheid. They lacked legitimacy and a natural reciprocal relationship with the broader social, cultural and economic environment (Mamphiswana \& Noyoo, 2002).

One way in which universities are drawn into the development framework is through the institutionalisation of community engagement (CE). The White Paper on the Transformation of Higher Education (Department of Education, 1997) sets out broad national goals and refers to community engagement as an integral and core responsibility of higher education, together with teaching and learning, and research. HEIs are called on to "demonstrate social responsibility and their commitment to the common good by making available expertise and infrastructure for community service programmes" (1997:10). Universities are also required through the function of community engagement in its various forms, including service learning, to develop and promote social and civic responsibilities in students, who are considered both agents and beneficiaries of community engagement.

A consequence of the formalisation of community engagement and the emphasis on promoting social and civic responsibilities in students is that discussions and research on graduate attributes are beginning, albeit at a slow pace, to be given more focused attention. For example, in its Charter of Graduate Attributes and Teaching and Learning Strategy Report (2009:1), the University of the Western Cape describes graduate attributes as:

qualities, values, attitudes, skills and understandings that a particular university sets out as being important for students to develop by the end of their studies. These attributes are both intended to equip them for future employment and as critical and responsible citizens, contributing to the social and economic wellbeing of society.

The Education White Paper emphasises that HEIs should produce graduates not only with the skills and competencies that build the foundations for lifelong learning, encompassing critical, analytical, problem-solving and communication skills, but they should also have the ability to deal with change and diversity, in particular, tolerance of different views and ideas (Department of Education, 1997).

Social work education and the profession generally are premised on the values emphasised above. However, it would be incorrect to assume that because an individual is a student of social work, he or she is socially responsible and will be so after university. In addition, it should not be assumed that the discipline of social work pedagogically and/or epistemologically inculcates social responsibility in students. Evidence of some social workers who have been involved in fraud and unethical behaviour in recent years bears testimony to the 
fact that social work as a discipline needs to pay attention to the inculcation of social responsibility in students in both the theory and practice of the discipline. Therefore, social work education and the profession in South Africa are challenged to purposefully incorporate the inculcation of social responsibility as an outcome of social work curricula.

The challenge is further exacerbated not only by the lack of national guidelines on how social responsibility is conceptualised and could be inculcated in university students, but also by the lack of relevant theoretical frameworks for community engagement and the development of student social responsibility. This lack of a theoretical framework has significant implications for the discipline and profession of social work. This paper attempts, albeit in a small way, to address the current gap in the literature on the potential of community potential through service learning to influence student development and social responsibility in the discipline of social work by asking the following questions: What does social responsibility mean? How can social responsibility be inculcated in students through community engagement service learning in social work education at universities? What theoretical framework generally and specifically relevant to social work education could guide the development of student social responsibility through service learning?

This paper presents the University of Fort Hare, Department of Social Work and Social Development, East London campus as a case study to demonstrate that the inculcation of social responsibility should not be taken for granted as being implicit in either the theoretical knowledge and/or practical component of social work. The case study also highlights the need for the academics of the Department of Social Work and Social Development, East London campus to consider adopting service learning into the social work curricula instead of adhering to the fieldwork practice of the past. The benefits of service learning extending beyond the student to include the community should be a critical factor in considering the change from fieldwork practice to service learning. Inculcating social responsibility in students during and after university should be a conscious and explicit goal of social work education.

The insights gained from the case study reveal the potential of social work education through the emphasis in community on "service" and "learning" to ideally advance the inculcation of social responsibility in social work students through their relationship and connection with others, which is key to effective social work. The first recommendation which is of value to all disciplines involved in service learning generally, but specifically relevant to social work, is for relational cultural theory (RCT) to serve as a theoretical framework guiding the development of social responsibility in students. And the second recommendation is for the systematisation of structured reflection and the inclusion of values education as integral to social work service learning and the development of social responsibility.

The case study is based on one department at a university and therefore cannot be considered representative of other universities. However, the possibility of similar findings being prevalent at other universities cannot be overlooked and the recommendations made are of value for social work education generally in South Africa and specifically for the inculcation of social responsibility in social work students.

\section{CONTEXTUAL AND CONCEPTUAL FRAMEWORK}

\section{Community engagement in South Africa}

Universities in South Africa are currently attempting to conceptualise or reconceptualise community engagement for their individual context and history in line with the national 
rationale for the formalisation of community engagement as a core function of universities. According to the rationale, universities are expected to contribute towards increasing levels of social and economic development, epistemic justice and equality, and to the holistic development of students, producing "well rounded and grounded" graduates with a strong sense of social and civic responsibilities (HEQC, 2006). This rationale is based on the assumption that universities would shift from the image of being disengaged, ivory-tower institutions set apart from communities to that of engagement and responsiveness to community needs through their students and academic staff.

The Higher Education Quality Committee (HEQC) describes community engagement as initiatives and processes through which the expertise of the higher education institutions in the areas of teaching and learning and research are applied to address issues relevant to their communities. It acknowledges that community engagement takes a variety of forms, ranging from informal and relatively unstructured activities to formal and structured academic programmes addressed at meeting particular community needs (HEQC, 2004b). Volunteerism and service learning are two examples of unstructured and structured community engagement respectively.

Volunteerism, categorised under the informal category, is viewed as the engagement of students in activities where the primary beneficiary is the recipient community and the primary goal is to provide a service. Volunteer programmes are viewed as altruistic by nature and are generally not related to, or integrated into, the student's field of study (CHE, 2004).

Service learning is considered formal and structured, and described as "applied learning which is directed at specific community needs and is integrated into an academic programme and curriculum. It could be credit-bearing and assessed, and may or may not take place in a workplace" (CHE, 2004:26). Service learning generally involves the integration of the curriculum with practical service by students in an activity that benefits members of the wider community beyond the classroom/lecture hall and engages students in structured reflection on their experience and learning (Lovat, Toomey, Clement, Crotty \& Nielsen, 2009). They add that service learning is associated with improved attitudes and actions relating to social and academic responsibility.

At a seminal conference on community engagement held in Cape Town in 2006 the critical role of students in the national transformation agenda was recognised and students were seen as both the agents and beneficiaries of community engagement, in a whole range of different models (CHE, 2007). At this conference the conceptualisation and under-theorisation of CE was also acknowledged as key challenges confronting universities in South Africa. These challenges were once again highlighted at a joint workshop on $\mathrm{CE}$ by the National Research Foundation (NRF) and the CHE in August 2008 (CHE, 2010). It is clear that the struggle to conceptualise and theorise community engagement in its various forms for higher education in the South African context is an ongoing one and consequently discussion or any literature on student social responsibility specifically is minimal or absent.

\section{Higher education and social responsibility}

Cetindamar and Hopkins (2008) assert that the main goal of higher education is still a matter of ongoing debate: whether it should be training for jobs, or preparing students to become stewards of the earth, or participants in democracy for global social justice. It is no secret that higher education institutions (HEIs) globally have failed to provide solutions to the social, economic and political problems of the world. Rather, their biased and dominant focus on 
producing students for the market economy and elevating the relentless pursuit of individual acquisition and accumulation has served to aggravate a world of uncertainty, marred by largescales of poverty and mass unemployment, hunger, violence and civil strife (Kane, 1999). As an acknowledgment of the current situation Prentice (2007:135) points out that many [faculty] academics are searching for methods to address "the growing individualization, and political and community alienation of younger adults".

In view of current global conditions universities are obliged to prepare students not only for the job market, but simultaneously educate them on a value system that will serve as a strong foundation for their ongoing participation in, and contribution to, human and community development, and as world citizens. Ideally, laying this foundation should start at the earliest level of education and continue as an ongoing educational process. Nevertheless, we propose that higher education generally, and specifically in the South African context, has a critical role to play in inculcating social responsibility in students.

While the various forms of CE are described in the Higher Education Quality Control national founding documents (HEQC 2004a, 2004b, 2006), exactly how HEIs are expected to develop social responsibility in students through $\mathrm{CE}$ is left to individual institutions. This may be problematic, as Cetindamar and Hopkins (2008) contend that educators have not usually been taught about issues of social and global responsibility in their own educational experiences. This state of affairs was even more prominent in social work education programmes at racially established universities during apartheid. Without a doubt, educators advocating for the inculcation of social responsibility in students would not have been tolerated by the apartheid regime. But in the current context of transition from apartheid to democracy, socially responsibility in students is promoted and supported by the national government, which in turn raises critical questions: What does social responsibility mean and how do universities "educate" students to be socially responsible in a democratic South Africa?

The current literature on social responsibility is largely related to corporate social responsibility. Davidson and Griffin (2000 cited in Fisher, 2004:392) define business social responsibility as "the set of obligations an organization has to protect and enhance the society in which it functions". Fisher (2004) points to the ethical dimension of social responsibility, which is also applicable to community engagement at higher education institutions, where ethics is a critical dimension specifically of social work. Even though this definition of social responsibility is uncontroversial, there is ongoing debate about how the concept can be given content (Fisher, 2004).

A definition of social responsibility which is relevant to community engagement at South African universities is that of social responsibility as "a sense of connection to those outside your circle of family and friends [and] ... an obligation to help those in the community, nation, or society-at-large who are in need" (Pancer \& Pratt, 1999 in Segal, 2011:268). Social responsibility has been described both as a natural tendency for justice that would occur without any human teaching and as a learned social behaviour (Witt \& Silver, 1994:330-331). The authors add that individuals with a high sense of social responsibility have been found to have deep concerns with broad social and ethical issues and a basic concern for what is right. Student social responsibility is viewed as having a valued outcome, as it facilitates learning and performance outcomes by promoting positive interactions with teachers and peers (Witt \& Silver, 1994:330-331). 
By definition, individuals with a comparatively high sense of social responsibility are predisposed to be concerned with the welfare of others and to take action on the basis of these concerns. Witt (2001:543) cites a number of writers who saw social responsibility as a composite of attitude elements reflecting behaviour that could be classified as reliable, accountable, loyal and doing an effective job. Social responsibility is a basic element in an individual's "helping personality" and measures of social responsibility are linked with measures of pro-social behaviour (Witt, 2001:543).

Social responsibility has a strong link with empathy and sensitivity, and if empathy is aroused, the welfare of others will be considered. When individuals obtain an accurate empathic perspective about the conditions and needs of others, they are more apt to feel social responsibility and become socially involved (Hoffman, 2000 in Segal, 2011:268). Goleman (2005) presents empathy as a dimension of emotional intelligence. Empathy means thoughtfully considering the feelings of others and is important in cross-cultural dialogue, which can easily lead to miscues and misunderstandings, especially in social work. People who are empathetic are attuned to subtleties in body language, can hear the message beneath the words being spoken, and have a deep understanding of both the existence and importance of cultural and ethnic differences (Goleman, 2005).

Segal (2011) differentiates between individual and social empathy, where social empathy is comprised of the following three components: individual empathy, contextual understanding and social responsibility. These three components lead to or extend the ability to understand people more deeply by perceiving or experiencing their life situations and as a result gain insight into structural inequalities and disparities. On a macro level empathy fosters people's involvement in social change, promotes social cooperation and increases civic involvement. The ability to experience empathy through an accurate contextual lens deepens one's understanding of society, leads to a belief in social responsibility and can result in social justice.

Social empathy provides a framework for more effective social policies that address disparities and support social and economic justice for all people. Segal (2011) asserts that social workers are well positioned to enhance social empathy and be socially responsible. Hoffman points out that social empathy is a combination of self-reflection and an accurate perspective or understanding of the underlying causes of social problems and their impact on communities, and it leads to a desire to take action and to improve societal well-being (Hoffman, 2000 in Segal, 2011:271).

Authors such as Omer (1979) and Immordino-Yang and Sylvan (2010) point out that showing consideration for others and acting with them is not antithetical to human nature, as we have been conditioned to believe in the Darwinian notion of "survival of the fittest". Similar to Omer (1979), who describes human nature as kind, compassionate and cooperative, Immordino-Yang and Sylvan (2010:3) write that neuro-imaging research has discovered that motivation for virtuous behaviour "is deeply rooted in the very systems that keep us alive, that make us act, that organize and regulate the functioning of our body". They add that recent neuroscience research shows that we are likely to be hardwired for many complicated behaviours, such as empathy and virtue, and hence social responsibility, and that our basis for empathetic action is embedded in our physiology. The challenge, according to Immordino-Yang and Sylvan (2010:3), "is to bring it forward and use it to support and improve social well-being". This raises a pertinent question for the discipline of social work at South African universities: How can social work education "bring forward" empathetic and virtuous behaviour and hence 
cultivate a sense of social responsibility in social work students as professionals and as contributing human beings to society beyond their professional responsibilities.

\section{Social work education and social responsibility}

The history of recent social work education and services in South Africa is rooted in the apartheid system of separate development and racial classification. Nicholas (2010:44) contends that "social work supported apartheid welfare structures and actively advocated segregation". The Social Work Act, No. 110 of 1978 legally defined the acts and activities of social workers as follows:

"Any act, activity or method directed at diagnosing, eliminating, preventing or treating social malfunctioning or problematic functioning in man, or at promoting social stability in man, and includes any process which is calculated to promote the efficient performance or application of such act, activity or method." (Bernstein \& Gray, 1996:64)

This definition focused on individual malfunctioning without any consideration of structural or environmental/community conditions affecting the healthy functioning of the individual. Consequently, social work education and practice focused mainly on individual problems and change (McKendrick, 1990). Aligned to the above definition, the three-year Social Work curriculum was changed to a four-year qualification in 1987 by the then Council for Social and Associated Workers and covered four major areas: social welfare policy and services; human growth, behaviour and the social environment; social work practice methodology; and field instruction (McKendrick, 1990). The curriculum content in the four major areas covered:

- Social welfare policy and services: social issues and problems; programmes and institutions designed to promote the quality of life and prevent and treat problems; historical and contemporary forces which influenced social welfare; the nature of social welfare systems; social policy and its impact on individuals and society; and the role of social workers in formulating policy and influencing appropriate change in social welfare institutions;

- Human growth, behaviour and the social environment: knowledge about human growth, physically, emotionally and intellectually; physical and mental health and ill-health; the influence of cultural values and norms; the central role of the family in human well-being; and how people function and meet their needs individually and in groups;

- Social work practice methodology: the direct helping methods, strategies and skills which social workers use in intervention with individuals, families, small groups, larger community groups and organisations. It also involved learning about the indirect or "enabling" methods of social work; research, supervision, social work education and administration/management;

- Field instruction or practical work: to take place concurrently with intellectual and theory learning. Unlike some other professions such as medicine and psychology, for example, social work students commence field instruction early in their course of study. Under the supervision of an experienced worker, individual students work directly with people either promotively, preventively or therapeutically, applying their theory knowledge and developing their helping skills. Practice and (theory) education come together in field instruction and by experiencing both concurrently, the student learns in a cyclical framework of "thinking" and "doing" (Lowe cited in McKendrick, 1987).

Field instruction or practical work took place concurrently with theoretical learning and this situation still remains the same to a large extent in a number of higher education institutions in 
the current context of outcomes-based education. It should be noted that, in line with British and American texts, community work in the form of community organising and social planning as a method of social work - and not community development - formed part of the curriculum. The emphasis was on social work with the individual, and the theory taught in the above areas in the apartheid context differed to a large extent from the reality of the majority of people in the country. Some or most of the theory could not be applied in practice to the lives of the majority within the apartheid development framework of racial classification and segregation. Social problems were interpreted as personal problems, thus placing the responsibility on the individual for the problem through the utilisation of micro approaches only, which were the main focus in social work education (Moscovitch \& Drover cited in Dlamini, 1995).

We should also note that there is no mention of the student's self-development or the inculcation of social responsibility in students in either the theory or practice components of the four-year curriculum. The idea of inculcating social responsibility in social work students would have been considered an alien and dangerous concept during the apartheid period, given the close link between social empathy and social responsibility, which has the potential to address disparities and support social and economic justice for all people (Segal, 2011). It is clear that the intention of field work practice was to develop the skills of the student. Making a contribution to the socio-economic development of oppressed communities was not part of the goal of fieldwork practice in social work education during the apartheid years.

Changes to welfare policy and legislation in a democratic South Africa after 1994 have challenged both social work education and services to rethink the way in which the social work curricula needed to be transformed to meet the requirements of a social development policy framework. The most common understanding of the developmental approach is that it "seeks to identify social interventions that have a positive impact on economic development" (Midgley \& Livermore cited in Kirst-Ashman, 2003:10). Education for the social service professions may be viewed as the interface between the university and the society, with a range of multifaceted connections occurring at a variety of levels within multiple sectors, including government organisations and community agencies. Universities are now required to produce graduates who are better prepared to apply their knowledge, values and skills in "real-world" settings and thus contribute to societal productivity and the overall wellbeing of all (Shera \& Bogo, 2001).

South Africa does not have its own definition of social work, but has adopted the internationally accepted definition developed by the International Federation of Social Workers and the International Association of Schools of Social Work (Hare, 2004:409), which reads as follows:

"The social work profession promotes change, problem-solving in human relationships and the empowerment and liberation of people to enhance well-being, Utilising theories of human behaviour and social systems, social work intervenes at the point where people interact with their environments. Principles of human rights and social justice are fundamental to social work."

The above definition of social work, centred on the principles of human rights and social justice, may be viewed as having been anathema to the apartheid definition of social work. Changes in social work education in the early 2000s to the outcomes-based four-year undergraduate Bachelor of Social Work (BSW) degree comprising twenty-seven outcomes is an attempt to prepare students with the relevant knowledge, values and skills to work in a developmental manner in a democratic context. What is clearly lacking in the BSW 
qualification is an outcome specifically committed to the self-development of students and their social responsibility. However, two of the nine purposes of the qualification that may be interpreted as giving some consideration to the self-development of students, albeit in a circuitous way are:

- An understanding of and the ability to demonstrate social work values and the principles of human rights and social justice while interacting with and assisting the range of human diversity;

- The skills to work effectively within teams, including social work teams, multi- and interdisciplinary teams as well as multisectoral teams (SAQA, 2009:2).

Earle (2008) points out that Social Work departments do not have standardised selection and admission criteria for students and that individual universities and faculties may or may not have selection criteria for admission into their Social Work programme. Most universities, including the University of Fort Hare, had to increase student intake into their Social Work programme as a consequence of the National Plan for Higher Education (Earle, 2008). The lack of non-academic selection processes is evident in a number of universities and, unfortunately, this situation has been exacerbated by the directive in the National Plan for Higher Education (Department of Education, 2001) to increase access of students to the Social Work degree programme (Earle, 2008). However, those who select candidates for education or jobs in social work "possess mental images of the kind of person they are seeking or seeking to avoid, even if they were hard put to describe the profile or reluctant to admit that one existed" (Clark, 2005 in Earle, 2008:93).

Earle's (2008:93) research provides a broad description of what are considered to be the characteristics of a "good" social worker: someone who has a "heart for people", who wants to help others, who has an "ear for listening", who knows how to make maximal use of minimal resources, who is good in decision making, who can think on her feet, who is able to communicate clearly and confidently with a diversity of people, who is emotionally balanced and does not carry heavy personal baggage, who does not suffer from mental illness, and who has a high sense of personal responsibility. These descriptions, however, are largely limited to the characteristics of the individual as a professional social worker and do not go far enough to locate the social worker as a socially responsible human being in the broader context of community and society. Characteristics such as the individual and social empathy integral to social responsibility have implications for the development of social work curricula from both a theoretical and service learning perspective.

The formalisation of community engagement as a core function of higher education institution may be viewed as a further challenge to social work education, as it requires all disciplines to think about how the inculcation of student social responsibility could be achieved through the various forms of community engagement. From a social work perspective, service learning is only beginning to be embraced by some universities such as the University of Stellenbosch. Green (2007) describes this as a response of the Department of Social Work at the University of Stellenbosch to the changing paradigm in social work and the changes in South African higher education structure and policy.

Service learning provides a different approach to integrate social work theory and practice. But even while service learning provides a mechanism for the inculcation of student social responsibility, it nevertheless presents a challenge to those universities which are deeply entrenched in the notion of fieldwork practice and are under-resourced. Universities that offer 
social work education need to examine the extent to which theory and fieldwork practice have the explicit intention to advance student self-development and the inculcation of social responsibility. Lemieux and Allen (2007:312) provide the following distinction between service learning and fieldwork practice in social work education: "with fieldwork practice, the emphasis is on developing student knowledge and skills; with service learning, the student's role is determined by the needs of the community they are serving [and] not by the learning goals of the student or the institution". Conversely, they claim that fieldwork practice experience emphasises student learning over the benefits of any community service or community engagement undertaken by the students. We should note that the pedagogy of service learning as part of the South African model of community engagement (and not community service) presumes that the university has a role to play in community development through its various programmes. Moore and Lan Lin (2009:7) confirm that this "model goes beyond the requirement that the engagement with the community is to prepare students for meaningful learning to an understanding of the role of the university once its resources are committed to community development. Universities have an important role in moving South Africa closer to its democratic ideals and vision".

Clearly, there is a marked difference in the intention of fieldwork practice as proposed in the original four-year programme of the Social Work curriculum, or even in the current outcomesbased programme, to the pedagogy of service learning as part of community engagement in contemporary South Africa. As an example, the case study of the Department of Social Work and Social Development, East London Campus of the University of Fort Hare (UFH) provides some insight into the lack of a social responsibility focus in social work education by adhering to the notion of fieldwork practice.

\section{THEORETICAL FRAMEWORK GUIDING THE STUDY}

\section{Relational cultural theory (RCT) as a theoretical framework for cultivating student social responsibility}

The development of social responsibility in university students requires a theoretical framework that locates students' self-development in relationships with others. Relational cultural theory (RCT), challenges the dominant model of human development that claims we move from dependence to autonomy as an inaccurate representation of human experience. It further questions the accuracy of a "separate self" paradigm for human development. The core idea of RCT is that all people grow through and toward connection (Jordan, 2008:2). RCT stresses the importance of the development of the self-with-others (Edwards \& Richards, 2002) rather than a purely individualistic perspective as posited by traditional psychodynamic theories, which stress the importance of the development of the self (Edwards \& Richards, 2002; Motulsky, 2010).

Spenser (2000 in Motulsky, 2010:1082) writes that the primary assumption underlying RCT is that as humans we have an innate capacity for, and desire to, engage in relationships with others and that the increasing capacity and development of mutual connection with others is the marker of healthy wellbeing. Therefore in RCT growth refers to increased self-knowledge, authentic connection to self and others, enhanced confidence, and increased motivation for progress. This theoretical approach assists in locating the individual firmly in a relational and cultural environment as real life requires constant interaction with others, contrary to the dominant individualistic ideology in Western culture (Edwards \& Richards, 2002:33). 
Just as community engagement, including service learning, places an emphasis on reciprocity in the relationship between academics, students and community partners, the major components of RCT are mutual engagement, mutual empathy and mutual learning. Thus the concept of mutuality (reciprocity in the current community engagement lexicon) is dialectical and not a linear process. More emphasis is given to fostering growth and mutually empathetic relationships as both the primary goal of development and the mechanism through which development occurs.

RCT also makes explicit the ways in which power dynamics in the family, culture and at societal levels affect people's wellbeing and recognises that even in such relationships disconnections will always occur. Disconnections, applied to community engagement service learning, may be a result of one of the partners (belonging either to the university or community) withdrawing from active participation in the engagement. If the disconnections can be addressed, the presumption in RCT is that stronger connections result. Connections and disconnections in relationships clearly highlight the need for reflection and reflective learning in community engagement, including service learning.

Of relevance to South Africa generally, and to social work in particular, is that social change and social justice underlie the RCT model of human development, which is particularly concerned with the disconnections and suffering caused by stratification, marginalisation and the exercise of dominance by one group over another. RCT challenges social conditions that generate the abuse of children; stereotyping of people of differing sexual orientation; and race, class and gender biases that prevent legitimate inclusion. Power dynamics in RCT are placed at the centre of understanding relationships and cover the complicated mix of social as well as personal change, specifically relevant for the inculcation of social responsibility (Comstock, Hammer, Strentzsch, Cannon, Parsons \& Salazar, 2008).

RCT challenges us to create social justice by paying attention to the power of mutual respect and mutual learning in ongoing growth-fostering relationships. The focus is on power-withothers, which unlinks the concept of power from the concept of domination. RCT highlights the importance of creating and protecting communities of possibility and hope for all people (Comstock et al., 2008). The transformation agenda of higher education promoted by the national government entails HEIs contributing towards addressing the disconnections caused by apartheid. When viewed from this perspective, the relevance of RCT for the development of social responsibility in students of social work through community engagement service learning lies in the notions of connections and disconnections, social change, social justice and power-with-others.

\section{Reflection as a key component of community engagement and social work education: systematisation of structured reflection}

Reflection is a crucial element in transforming concrete experience, such as that derived from community engagement service learning, into knowledge. In writing on the role of reflection in service learning (and CE for the South African context), Bringle and Hatcher (1996) state that by focusing on what the specific concrete experience means to the student, the student creates a worldview or lens which determines his or her future behaviour and strategies. Reflection assists in gaining a deeper understanding of module content, a broader appreciation of the discipline, and/or an enhanced sense of personal values and social responsibility. Reflection is a critical element in transforming, clarifying, reinforcing and expanding concrete experience into knowledge, including knowledge of self (Bringle \& Hatcher, 1996). 
Boud and Walker (1998) write on the importance of the context in which reflective action is engaged. They view the context, which encompasses the cultural, social and political environment in which reflection takes place, as the single most important influence on reflection and learning, because it impacts on who we are, what and how we think, what we regard as legitimate knowledge, and the ways in which we relate to others. Reynolds (2011) adds that the learning derived from reflecting on experience is critical to human development, because the learning is situated within a specific context and this process not only involves the application of knowledge, but the development of ideas which we carry with us into the future.

Systematising reflection ensures that reflection becomes a deliberate and regular habit for social work students, as this means resisting the temptation to just keep going from one activity to another. Reflection makes the connections, and it is a powerful key to student's success, growth, learning and even transformation through community engagement service learning activities.

Reynolds (2011) points out that developing productive reflection requires patience, practice, discipline and setting aside time to think, which would be an asset to a social worker professionally and personally. Reflection contributes to self-awareness in students and needs to be more than a consideration of the technical and organisational aspects of presenting problems.

It should also mean raising social, political and cultural issues, questioning purposes and intentions and, if necessary, challenging the assumptions and taken-for-granted ideas on which organisational/socio-economic policies and practices are based. This means in practice that the process of thoughtfully examining experiences is informed by ideas that are capable of helping us to make sense of social and political, not just technical, processes. This kind of critical reflection lends itself to the notion of seeing education not simply as serving the function of shaping people for the workplace, but as preparation for life (Reynolds, 2011).

Critical reflection is important in the context of action learning and a more critically informed approach to reflective practice should include questioning and challenging existing structures and practices. When applied to service learning, students need to question and reflect on whether service learning activities in a particular context reinforce existing power relations in the community or transforms them (Reynolds \& Vince, 2004 in Reynolds, 2011:9).

However, Reynolds (2011) cautions that critically reflective practice is not going to be welcome to everyone, especially if it involves challenging ends as well as means, and posing questions that have implications for the power structures underlying existing policy and practice. As a solution Alvesson and Wilmott (1992 in Reynolds, 2011:12) offer the "incremental" approach as a constructive form of critical reflection, with a focus on specific processes, which fits well with the practice of action learning. However, the role of social work students as change agents should not be overlooked in the reflective process.

The impact that students will have on their work, their community, and their social and physical environment demands the systematisation of structured reflection of service learning activities at universities.

\section{Inclusion of values education in all forms of community engagement, including service learning}

Values education has been mooted as important for South African education since 2000, along with the Moral Regeneration Programme. Not much has been said about these two issues from 
an educational perspective generally, or specifically from a higher education perspective. Community engagement and social work are relationally oriented and therefore values such as respect, caring and concern for others, justice and connectedness need to be part of the students' repertoire prior to engagement with individuals, groups and communities. Values education fits comfortably with, and complements, relational cultural theory as a framework for community engagement generally and social work service learning in particular in the South African context.

New neuroscience research shows that effective learning requires a response that is as much about affect and social dynamics as about cognition (Bruer, 1999 in Lovat et al., 2009). Effective learning is inherently values filled and is increasingly seen as a pedagogical imperative that incorporates the moral, social, emotional, physical, spiritual and intellectual aspects of human development, what is referred to as the whole person approach to learning. We fully agree that a values approach to service learning in social work will only serve to maximise academic success, student development and community wellbeing (Lovat et al., 2009).

\section{RESEARCH DESIGN AND METHODOLOGY}

The study was exploratory in design and utilised qualitative methodology and the case study method. Case studies, according to Dumont and Sumbulu (2010), are important for social work, since they provide a holistic portrayal of a client's/student's experiences and results regarding a programme. The case can be an individual, an event, an organisation or a community. The University of Fort Hare (UFH), Department of Social Work and Social Development, East London Campus was adopted as the case for study here. The sample of the study comprised 60 fourth-year Social Work students and the academic staff member responsible for the coordination of the Department's fieldwork practical programme. Data were collected from the student sample using an evaluation questionnaire, while a semi-structured interview schedule was used to gather data from the fieldwork practice coordinator.

\section{Case study: the Department of Social Work and Social Development, University of Fort Hare}

Social Work is offered on the Alice and East London campuses of the University of Fort Hare in the Eastern Cape Province. The Department of Social Work and Social Development of the UFH derived its name from combining the Department of Social Work, Alice Campus with the Department of Social Development, East London Campus (formerly of Rhodes University), which was merged with the UFH in 2004. The Community Engagement directorate of UFH was established in 2009 and a database of all community engagement activities, including service learning is currently being established.

The Department of Social Work and Social Development, University of Fort Hare, East London Campus adheres to the concept of field work practice and not service learning to refer to students' engagement with the community.

\section{The research question}

As service learning is not a part of the social work lexicon of the academics of the Department of Social Work and Social Development, and given that social responsibility is an expected outcome of community engagement service learning, the following question arises: What attention, if any, is given to the development of student social responsibility in the Social Work 
programme of fourth-year students at the Department of Social Work and Social Development, East London Campus of the UFH?

In order to answer the above question, the fieldwork practice programme of the Department of Social Work and Social Development, East London Campus of the University of Fort Hare was explored to determine the extent to which students' self-development and the inculcation of social responsibility was directly taken into consideration in the planning, preparation and execution of field work practice. An assumption was made that, because of the nature of social work as a social service profession, the development of student social responsibility would be afforded priority in students' integration of theory and practice or experiential learning.

\section{The research process}

In 2010 a total of 60 social work students were in their fourth year on the East London Campus of the UFH. The fieldwork practice coordinator was interviewed at the beginning of November 2010. The coordinator thought that the students were involved in "service learning", because they were engaging with the local communities as part of their fieldwork practice. The academic staff of the Department, however, preferred using the term "field work practice" and not "service learning". She stated that students are academically prepared for fieldwork practice in the different methods of social work prior to placement. The fourth-year students were placed in human service organisations from the beginning of 2010 for the purpose of integrating theory with practice in the three methods of social work: working with individuals; working with groups; and working with communities.

Students, staff and supervisors evaluate students' experiential learning after a period of six months. At the end of October 2010 students were required to complete an evaluation questionnaire developed by the academic staff of the Department with regards to their fieldwork practice. The questionnaire focused on the student's performance as a professional working with individuals (case work), groups (group work) and communities (community development). Students also had to evaluate themselves as leaders. The questionnaire did not include any questions on student development, self-knowledge, community benefit or social responsibility. For the purpose of this study, students' evaluations of themselves as professionals and leaders were analysed. Of the total of 60 final-year students, 38 had completed their evaluations by the first week in November 2010, when the analysis was done.

\section{Findings of the study}

- Students' evaluation of self as professionals

Common responses to students' evaluation of themselves as professionals included: being respectful, compassionate and empathetic, good listening and communication skills, problemsolving skills, teamwork, confidentiality, punctuality and being neutral, and not putting their own beliefs and values first (being objective). It should be noted that the term "empathetic" is used to describe the student as a professional/technicist, not as an understanding of oneself as a human being in relation to others, the context or broader society, that is, from a macro social perspective that could "lead to a desire to take action and to improve societal well-being" (Hoffman, 2000 in Segal, 2011:271).

Interestingly, 13 of the 38 students mentioned that they were emotionally involved or became emotional as a result of the kind of problems experienced by clients. They clearly saw this as being unprofessional behaviour and therefore needed to strengthen themselves in this area, meaning not to be emotional, to become more objective. Only three students provided responses that may be categorised as reflective in relation to self and others. One student said: 
"I was not strong enough, although I had evaluated my own values, needs, communication style and how these impact on others. [Need to] explore my personal myths, beliefs and how I see myself developing."

Another student's response was:

"The practical programme has given me the opportunity to evaluate myself and the capabilities I possess, which I previously may not have recognised - effective communication, listening, respect and empathy."

- Students' evaluation of themselves as leaders

Common responses to students' evaluation of themselves as leaders included the following qualities: effective time management, taking responsibility/initiative for arranging casework and group work, being strong and having confidence, thinking creatively, being disciplined and able to work well under pressure.

\section{Fieldwork practice coordinator's responses}

The fieldwork practice coordinator was asked the following questions:

- To what extent was community engagement and social responsibility, students' knowledge of self and development considered a part of the fieldwork practice programme?

- To what extent were self-awareness and reflection processes a continuous part of students' education?

The coordinator's responses to these two questions were brief and telling. Firstly, the evaluation of fieldwork practice by the students did not provide a space for reflection on students' self-development, community engagement and social responsibility. Students' assessments were made from the perspective of fieldwork practice and not service learning, were and based on their ability to implement theory related to the three methods of social work (casework, group work and community development) into practice. According to the fieldwork coordinator, there was very little understanding and discussion of service learning as part of community engagement, its function with regards to inculcating and promoting student social responsibility and the broader purpose of community engagement in the national transformation agenda of higher education institutions.

Secondly, the focus of students' learning was still dominated by professional knowledge and technical skills. As such, student self-evaluation and supervisor's formal assessment of students were based mainly on discipline-oriented knowledge. A student's knowledge of his/her individual self in relationship with others who were not "clients" was not considered in the evaluation and assessment procedures, mainly because it was not part of the theoretical content of the social work education programme. There were no formal processes for developing selfawareness and for reflection. The coordinator mentioned that she sometimes asked students at the end of the "fieldwork" assessment process: What impact, if any, did the "fieldwork" have on their self-development? However, this was not consistent with all students, nor was it a structured, formal process in the Department of Social Work and Social Development, East London Campus of the UFH.

\section{CONCLUSION AND RECOMMENDATIONS}

Service learning and the focus on social responsibility could be viewed as future oriented in relation to the student's role as a citizen and human being. Social work as a discipline needs to educate students for life and not only for a living. We propose that student social responsibility 
should be one of the key objectives of service learning in social work education generally and specifically at the UFH.

Relational cultural theory (RCT) is recommended as a theoretical framework for the development of student social responsibility generally, and specifically for social work education through the various forms of community engagement, including service learning, at South African universities. The second recommendation of the study is in line with Hoffman's view of social empathy as a combination of self-reflection and an accurate perspective or understanding of the underlying causes of social problems and their impact on communities, which should lead to a desire to take action and to improve societal wellbeing (Hoffman, 2000 in Segal, 2011:271). The study recommends the systematisation of structured reflection (understood as a socially situated, relational, political and collective process) and values education to be integral parts of social work service learning/fieldwork practice.

\section{REFERENCES}

BERNSTEIN, A. \& GRAY, M. 1996. Social work: a beginners text. Dalbridge: Juta.

BOUD, D. \& WALKER, D. 1998. Promoting reflection in professional courses: the challenge of context. Studies in Higher Education, 23(2):191-206.

BRINGLE, R.G. \& HACHTER, A.J. 1996. Implementing Service Learning in Higher Education. Journal of Higher Education, 67(2):221-239.

CETINDAMAR, D. \& HOPKINS, T. 2008. "Enhancing students' responsibility towards society through civic involvement projects". Innovations in Education and Teaching International, 45(4):401-410.

COUNCIL ON HIGHER EDUCATION (CHE). 2004. South African Higher Education in the First Decade of Democracy. Pretoria: Government Printers.

COUNCIL ON HIGHER EDUCATION (CHE). 2007. Community Engagement in Higher

Education. Proceedings of the Community Engagement in Higher Education Conference: 3-5 September 2006, Bantry Bay Pretoria: Council on Higher Education.

COUNCIL ON HIGHER EDUCATION (CHE). 2010. Community Engagement in South African Higher Education. Pretoria: Government Printers.

COMSTOCK, D.L., HAMMER, T.R., STRENTZSCH, J., CANNON, K., PARSONS, J. \& SALAZAR, G. 2008. Relational cultural theory: a framework for bridging relational, multicultural, and social justice competencies. Journal of Counselling and Development, 86:279-286.

DEPARTMENT OF EDUCATION. 1997. Education White Paper 3: a programme for higher education transformation. Pretoria: Government Printers.

DLAMINI, P.M. 1995. Inequality and underdevelopment: issues for a social development curriculum. Journal of Social Development in Africa, 10(2):23-33.

DUMONT, K. \& SUMBULU, A. 2010. Social work research and evaluation. In: NICHOLAS, L., RAUTENBACH, J. \& MAISTRY, M. (eds) Introduction to Social Work. Claremont: Juta.

EARLE, N. 2008. Social work in social change: the profession and education of social workers in South Africa. Cape Town: HSRC Press. 
EDWARDS, J.B. \& RICHARDS, A. 2002. Relational teaching. Journal of Teaching in Social Work, 22(1):33-48.

FISHER, J. 2004. Social responsibility and ethics: clarifying the concepts. Journal of Business Ethics, 52(4):391-400.

GOLEMAN, D. 2005. What makes a leader? Harvard Business Review on the mind of the leader. Boston: Harvard Business School Publishing Corporation.

GREEN, S. 2007. Redesigning practice-education modules in social work as service-learning modules. 2009. In: MOORE, E. \& LAN LIN, P. Service-learning in higher education: paradigms and challenges. Indianapolis: University of Indianapolis Press: 85-96.

HARE, I. 2004. Defining social work for the $21^{\text {st }}$ century. The International Federation of Social Workers' revised definition of social work. International Social Work, 3(47):406-424.

HIGHER EDUCATION QUALITY COMMITTEE SOUTH AFRICA (HEQC). 2004a. Framework for Institutional Audits. Pretoria: Council on Higher Education.

HIGHER EDUCATION QUALITY COMMITTEE SOUTH AFRICA (HEQC). 2004b. Criteria for Institutional Audits. Pretoria: Council of Higher Education.

HIGHER EDUCATION QUALITY COMMITTEE (HEQC). 2006. A Good Practice Guide and Self-evaluation Instruments for Managing the Quality of Service-Learning. Pretoria: Council of Higher Education.

IMMORDINO-YANG, M.H. \& SYLVAN, L. 2010. Admiration for virtue: neuroscientific perspectives on a motivating emotion. Contemporary Educational Psychology, 35:110-115.

JORDAN, J.V. 2008. Recent developments in relational-cultural theory. Women and Therapy, 31(2):1-4.

KANE, J. (ed) 1999. Education, information and transformation: essays on learning and thinking. New Jersey: Prentice-Hall Inc.

KIRST-ASHMAN, K. 2003. Introduction to social work and social welfare: critical thinking perspectives. Pacific Grove: Brooks/Cole-Thomas Learning.

LEMIEUX, C.M. \& ALLEN, P.D. 2007. Service learning in social work education: the state of knowledge, pedagogical practicalities, and practice conundrums. Journal of Social Work Education, 43(2):309-325.

LOVAT, T., TOOMEY, R., CLEMENT, N., CROTTY, R. \& NIELSEN, T. 2009. Values education, quality teaching and service learning. A troika for effective teaching and teaching education. Terrigal NSW: David Barlow Publishing.

MAMPHISWANA, D. \& NOYOO, N. 2002. Social work education in a changing sociopolitical and economic dispensation: perspectives from South Africa. International Social Work, 43(1):21-32.

McKENDRICK, B. 1987. Introduction to social work in South Africa. Pinetown: Owen Burgess Publishers.

McKENDRICK, B. 1990. Introduction to social work in South Africa. Pretoria: HAUM Tertiary. 
MOORE, M. \& LAN LIN, P. 2009. Emerging service-learning paradigms in higher education. In: MOORE, M. \& LAN LIN, P. (eds) Service-learning in higher education: paradigms \& challenges. Indianapolis: University of Indianapolis Press.

MOTULSKY, S.L. 2010. Relational processes in career transition; extending theory, research, and practice. The Counselling Psychologist, 38(8):1078-1114.

NICHOLAS, L. 2010. The history of South African social work. In: NICHOLAS, L., RAUTENBACH, J. \& MAISTRY, M. (ed) Introduction to Social Work. Cape Town: Juta.

OMER, S. 1979. Social development. International Social Work, 22:11-26.

PATEL, L. 2005. Social welfare and social development in South Africa. Cape Town: Oxford University Press.

PRENTICE, M. 2007. Service learning and civic engagement. Acad. Quest, 20:135-148.

REYNOLDS M. 2011. Reflective practice: origins and interpretations. Action Learning Research and Practice, 8(1):5-13.

SOUTH AFRICAN QUALIFICATIONS AUTHORITY (SAQA). 2009. Bachelor of Social Work Degree (BSW).

SEGAL, E.A. 2011. Social empathy: a model built on empathy, contextual understanding, and social responsibility that promotes social justice. Journal of Social Service Research, 37(3):266-277.

SHERA, W. \& BOGO, M. 2001. Social work education and practice: planning for the future. International Social Work, 44(2):197-210.

UNIVERSITY OF THE WESTERN CAPE. 2009. Charter of Graduate Attributes and Teaching and Learning Strategy Report.

WITT, L.A. \& SILVER, N.C. 1994. The effects of social responsibility and satisfaction on extrarole behaviours. The Basic and Applied Social Psychology, 75(3):329-338.

WITT, L.A. 2001. Person-Situation Effects and Gender Differences in the Prediction of Social Responsibility. The Journal of Social Psychology, 130(4):543-553.

Dr Margie Maistry is currently a postdoctoral research fellow at the University of Fort Hare working under the SARCHI Chair of Social Change and the Community University Partnership Programme (CUPP), funded by the National Research Foundation (NRF) 